\title{
Breaking trade-off in nitrogen management and sustainability
}

\author{
Akihiko Terada ${ }^{1}$
}

Published online: 11 September 2017

(C) Springer-Verlag GmbH Germany 2017

It is not always easy to find a win-win relation in food, environment, energy and sustainability regarding nitrogen. By virtue of an invention of the Haber-Bosch process where inert nitrogen, i.e. $\mathrm{N}_{2}$, is converted into ammonia, a main constituent of "reactive" nitrogen, we have been able to produce more fertilizers, contributing to an increase in food production. Nevertheless, the groundbreaking invention triggered overdose of fertilizer application, which resulted in nitrogen pollution in water bodies. As reviewed elsewhere (Shibata et al. 2017), the trade-off between food production and nitrogen pollution, termed " $\mathrm{N}$ dilemma," is arisen. In engineered systems for nitrogen-containing wastewater treatment, reactive nitrogen is biologically converted into inert nitrogen. To this end, aeration is essential to oxidize ammonia into nitrite/nitrate, necessitating energy and cost. In order to save the aeration energy, limiting oxygen supply has been implemented. However, this option boosts emissions of nitrous oxide $\left(\mathrm{N}_{2} \mathrm{O}\right)$ known as an ozone-depleting and highly potent greenhouse gas. Thus, another trade-off occurs between cost-effectiveness and greenhouse gas emission in wastewater treatment systems.

We are in the period when nitrogen cycle is taken into consideration for its pollution abatement. According to the report on the planetary boundaries approach (Rockstrom et al. 2009), nitrogen pollution has been highly alerted because it makes the earth irreversibly vulnerable (Rockstrom et al. 2009) and the magnitude of the risk has become

Akihiko Terada

akte@cc.tuat.ac.jp

1 Department of Chemical Engineering, Tokyo University of Agriculture and Technology, 2-24-16 Naka, Koganei, Tokyo 184-8588, Japan more serious (Steffen et al. 2015). This threatening condition will continue or may become even worse in the twenty-first century owing to an increase in the amount of nitrogen fixed from the atmosphere for human activities. It has been reported that climate changes and land use due to population growth will further increase the total amount of fixed nitrogen by approximately $30 \%$ from 2010 to around 2100 (Fowler et al. 2015). This indicates that we will face situations: (1) where reactive nitrogen remaining in terrestrial, marine and soil environments needs to be converted into inert nitrogen; and (2) where the amount of used reactive nitrogen needs to be reduced. Unless these situations are resolved, further nitrogen pollution would be anticipated, posing risks of water pollution, human health and global warming.

That being said, the situations seem to be changing. Indeed, more stringent regulations for reactive nitrogen emissions and discharges in developed countries have been enforced to deter air and water pollutions, which reduce the amount of reactive nitrogen to the atmosphere and water bodies. From engineering standpoint, the application of nanotechnology to agricultural plants, named phytonanotechnology (Rajan et al. 2015), would be promising to reduce the amount of fertilizes applied to a cropland (Kottegoda et al. 2017). Developing a wastewater treatment system to mitigate $\mathrm{N}_{2} \mathrm{O}$ emission and to enhance nitrogen removal by harnessing novel microorganisms could be feasible.

I had a chance to attend the Fifth International Conference on Nitrification and Related Processes (in Vienna from 23rd to 27th July 2017) where the concept "low N-footprint" was extensively introduced and discussed. Given that meat has a higher N-footprint than vegetables, all served foods during the conference were vegetarian. There was a special workshop "Ecological Impact of the 
Global N-Cycle and Perspectives for Sustainability." The lectures encouraged the participants to seriously think of contributing to a low $\mathrm{N}$-footprint society.

Individual nitrogen consumption in food and energy should be also taken into consideration as nitrogen management. In this regard, the N-calculator (http://www.nprint.org) can be suggested for developing public awareness. This $\mathrm{N}$-calculator is based on $\mathrm{N}$-footprint per capita resultant from the amount of reactive nitrogen loss to the environment by incorporating consumed food and energy, as well as required nitrogen to produce food and goods (Leach et al. 2012). The challenge, however, is to disseminate information about nitrogen footprints of food, energy and environmental issues. Hopefully when a critical mass of the population becomes concerned about nitrogen pollution, innovative solutions to the nitrogen trade-offs will emerge.

\section{References}

Fowler D, Steadman CE, Stevenson D, Coyle M, Rees RM, Skiba UM, Sutton MA, Cape JN, Dore AJ, Vieno M, Simpson D, Zaehle S, Stocker BD, Rinaldi M, Facchini MC, Flechard CR, Nemitz E, Twigg M, Erisman JW, Butterbach-Bahl K, Galloway
JN (2015) Effects of global change during the 21st century on the nitrogen cycle. Atmos Chem Phys 15(24):13849-13893

Kottegoda N, Sandaruwan C, Priyadarshana G, Siriwardhana A, Rathnayake UA, Arachchige DMB, Kumarasinghe AR, Dahanayake D, Karunaratne V, Amaratunga GAJ (2017) Ureahydroxyapatite nanohybrids for slow release of nitrogen. ACS Nano 11(2):1214-1221

Leach AM, Galloway JN, Bleeker A, Erisman JW, Kohn R, Kitzes J (2012) A nitrogen footprint model to help consumers understand their role in nitrogen losses to the environment. Environ Dev 1(1):40-66

Rajan R, Chandran K, Harper SL, Yun SI, Kalaichelvan PT (2015) Plant extract synthesized silver nanoparticles: an ongoing source of novel biocompatible materials. Ind Crops Prod 70:356-373

Rockstrom J, Steffen W, Noone K, Persson A, Chapin FS, Lambin EF, Lenton TM, Scheffer M, Folke C, Schellnhuber HJ, Nykvist B, de Wit CA, Hughes T, van der Leeuw S, Rodhe H, Sorlin S, Snyder PK, Costanza R, Svedin U, Falkenmark M, Karlberg L, Corell RW, Fabry VJ, Hansen J, Walker B, Liverman D, Richardson K, Crutzen P, Foley JA (2009) A safe operating space for humanity. Nature 461(7263):472-475

Shibata H, Galloway JN, Leach AM, Cattaneo LR, Cattell Noll L, Erisman JW, Gu B, Liang X, Hayashi K, Ma L, Dalgaard T, Graversgaard M, Chen D, Nansai K, Shindo J, Matsubae K, Oita A, Su MC, Mishima SI, Bleeker A (2017) Nitrogen footprints: regional realities and options to reduce nitrogen loss to the environment. Ambio 46(2):129-142

Steffen W, Richardson K, Rockström J, Cornell SE, Fetzer I, Bennett EM, Biggs R, Carpenter SR, de Vries W, de Wit CA, Folke C, Gerten D, Heinke J, Mace GM, Persson LM, Ramanathan V, Reyers B, Sörlin S (2015) Planetary boundaries: guiding human development on a changing planet. Science 347(6223):1259855 